\title{
10 Mayıs 1997 Qa'enat (İran) Depremi (Mw=7.2) Sonlu-Fay Kayma Dağılımının Telesismik P ve SH Geniș Bant Dalga Șekillerinin Ters Çözümünden Belirlenmesi
}

\section{Finite-Fault Slip Distribution of the 10 May 1997 Qa'enat (Iran), Earthquake (Mw=7.2) Determined From Inversion of the Teleseismic $P$ and SH Broad Band Waveforms}

\section{HATICE DURMUȘ ${ }^{1 *}$, MURAT UTKUCU ${ }^{2}$}

1 Dumlupınar Üniversitesi Mühendislik Fakültesi Jeoloji Mühendisliği Bölümü, Kütahya

${ }^{2}$ Sakarya Üniversitesi Mühendislik Fakültesi Jeofizik Mühendisliği Bölümü, 54187 Serdivan/Sakarya.

Geliș (received) : 20 Mayıs (May) 2018

Kabul (accepted) : 23 Kasım (November) 2018

öz

Bu çalıșmada, 10 Mayıs 1997 Qa'enat depreminin (Mw=7.2) sonlu-fay kırılma özellikleri araștııılmıștır. Hartzell ve Heaton (1983) tarafından geliștirilen bir lineer sonlu-fay ters çözüm yöntemi sonlu-fay kaynak özelliklerini elde etmek için geniș bant telesismik P ve SH cisim dalga șekillerine uygulanmıștır. 1997 Qa'enat depreminin çoklu-segment sabit rake açlı sonlu-fay modeli, kırılmanın üç pürüzün yenilmesiyle kontrol edildiğini, en büyük kaymanın $340 \mathrm{~cm}$ ile ortada yer alan pürüz üzerinde olduğunu, güneye

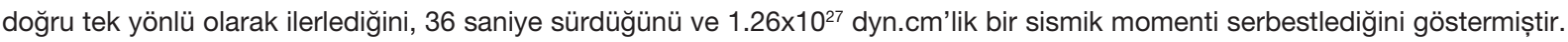
Kuzeydeki pürüz 30×15 km²'lik bir kırılma alanı ile $220 \mathrm{~cm}$ maksimum kayma genliğine ve güneydeki pürüz $12 \times 15$ km²'lik bir kırılma alanı ile $220 \mathrm{~cm}$ maksimum kayma genliğine sahiptir. Benzer bir kayma dağılım modeli, kayma genliklerinde küçük farklılıklar ve daha sığ güney pürüz ile rake açısının $90^{\circ}-180^{\circ}$ aralığında değișimine izin verildiğinde de elde edilmiștir. Ayrıca değișken rake açılı ters çözüm, depremin baskın olarak sağ yanal kayma nedeniyle olduğunu ve arazide gözlendiği gibi güney pürüzde önemli bir ters kayma bileșenine sahip olduğunu göstermiștir. Değișken rake açılı ters çözüm için sismik moment $1.18 \times 10^{27}$ dyn.cm olarak hesaplanmıștır.

Anahtar Kelimeler: Iran, Lut Bloğu, Sonlu-fay modellemesi, 10 Mayıs 1997 Qa'enat depremi.

\begin{abstract}
In the present study, finite-fault rupture properties of the 10 May 1997 Qa'enat, Iran, earthquake (Mw=7.2) have been investigated. A linear finite-fault inversion method developed by Hartzell and Heaton (1983) is applied to the broadband teleseismic P and SH body waveforms in order to obtain the finite-fault source properties. The multi-segment, fixed-rake angle finite-fault modeling of the 1997 Qa'enat earthquake has shown that the rupture was controlled by failure of three asperities with a maximum slip of about $340 \mathrm{~cm}$ over the asperity in the middle, was unilateral to the south, lasted for $36 \mathrm{~s}$ and released a seismic moment of $1.26 \times 10^{27} \mathrm{dyn}$. $\mathrm{cm}$. The asperity in the north has maximum slip amplitude of $220 \mathrm{~cm}$ with a rupture area of $30 \times 15 \mathrm{~km}^{2}$ and the asperity in the south has maximum slip amplitude of $220 \mathrm{~cm}$ with a rupture area of $12 \times 15 \mathrm{~km}^{2}$. A similar slip distribution model has been obtained when the rake-angle allowed to vary in the range $90^{\circ}-180^{\circ}$ with small differences in slip amplitudes and a shallower southern asperity. The variable-rake angle inversion has further shown that the earthquake was due to dominantly dextral slippage and the southern asperity has a significant reverse slip component as observed in the field. A seismic moment of $1.18 \times 10^{27}$ dyn.cm was estimated for the variable-rake angle inversion.
\end{abstract}

Keywords: Iran, Lut Block, Finite fault modelling, 10 May 1997 Qa'enat earthquake.

\footnotetext{
${ }^{*} \mathrm{H}$. Durmuş

e-posta: hatice.durmus@dpu.edu.tr
} 


\section{Giriș}

10 Mayıs 1997 Qa'enat depremi $(M w=7.2)$, Lut Bloğu'nun KB'sını sınılayan Abiz Fayı üzerinde meydana gelmiștir (Șekil 1). Kuzeyde Dasht-e-Bayaz fayından güneyde Sepestan Dağına kadar uzanan bu fay üzerinde olușan yaklașık $125 \mathrm{~km}$ uzunluğunda çok segmentli KB-GD genel doğrultulu sağ-yanal doğrultu atımlı yüzey kırığı (Ikeda vd., 1999; Berberian vd., 1999; Sudhaus ve Jonsson, 2011) İran depremleri ile ilișkili bilinen en uzun yüzey kırı̆ı̆ıdır ve kırığın kuzey kısmı daha önce 1936 ve 1979 depremleri ile kırılmıștır (Berberian vd., 1999) (Șekil 2).

U.S. Geological Survey (USGS) tarafından dıș merkez koordinatları $33.83^{\circ} \mathrm{K}-59.81^{\circ} \mathrm{D}$ (Șekil 1b) ve odak derinliği $10 \mathrm{~km}$ olarak verilen (Çizelge 1) depremde 1500 'den fazla insan hayatını kaybederken 2600 'den fazla insan yaralanmıș ve 12.000 civarı ev yıkılmıștır (Berberian vd., 1999; Walker vd., 2011). Grünthal vd. (1999) bu bölgenin doğu İran'daki en yüksek sismik tehlikeye sahip bölge olduğunu vurgulamıștır. Birçok araștırmacı ve sismoloji merkezi tarafından 1997 Qa'enat depreminin kaynak mekanizma çözümleri çeșitli veri setleri kullanılarak yapılmıștır (Çizelge 1). Bütün bu çözümler deprem için sağ-yanal doğrultu atımlı faylanmaya ișaret etmektedir.

İran, kıta-kıta çarpıșması (Zagros, Alborz, Kopet Dag), okyanusal litosferin kıtasal litosfer altına dalımı (Makran) ve genç orojen ile dalma-batma zonu arasındaki keskin geçiș (Minab-Zendan-Palami Fay Sistemi (MZPFS)) gibi tektonik süreçlerin karșılașıldığı doğal bir laboratuvar niteliğindedir (Vernant vd., 2004) (Șekil 1a). İran'daki aktif deformasyon güneyde Arabistan plakası ile kuzeyde Avrasya plakası arasındaki yakınsamadan kaynaklanmaktadır (Berberian, 1981; Jackson ve McKenzie, 1984; Talebian ve Jackson, 2002) ve çarpıșan bu iki plaka arasındaki sıkıșma zonundaki konumundan dolayı İran, dünyadaki sismik olarak en aktif bölgelerden biridir (Engdahl vd., 2006). Ambraseys ve Melville (1982), tüm İran'da 1900 yılından bu yana büyüklüğü $M>7.0$ olan bir depremin her 7 yılda bir, büyüklüğü $6.0<\mathrm{M}<7.0$ olan bir depremin ise her iki yılda bir meydana geldiğini vurgulamıștır.

Vernant vd. (2004) tarafından elde edilen GPS kabuksal hız alanı, Arabistan plakasının Avrasya'ya göre $22 \pm 2 \mathrm{~mm} / \mathrm{y}$ ll hızla hemen hemen kuzeye doğru hareket ettiğini ortaya koymaktadır (Șekil 1a). Yakınsama hareketinin yatay bileșeni Zagros'ların kuzeyindeki sağ-yanal doğrultu atımlı Main Recent Fayı (MRF) ile, düșey bileșeni ise orta Zagros Bindirme Kușağı
(ZBK) ile karșılanmaktadır. ZBK, yakınsamanın $7 \pm 2$ mm/yıllık kısmını karșılarken MRF boyunca sağyanal yer değiștirmeler yaklașık $3 \pm 2 \mathrm{~mm} / \mathrm{yl}$ 'dır (Vernant vd., 2004) (Șekil 1a). Güneyde Makran dalmabatması tarafından karșılanmayan Arabistan ve Avrasya yakınsamasının bir kısmı doğu İran'da Lut Bloğundaki doğrultu atımlı faylar araclığı ile Kopet Dag bindirme-kıvrım kușağına aktarılmaktadır ve birçok ters fay ile bu kușak güneyde Orta İran bloğundan ayrılmaktadır (Berberian, 1981). Vernant vd. (2004)'e göre Kopet Dag'da yakınsama hareketinin $6 \pm 2 \mathrm{~mm} /$ yıllık kısmı karșılanmaktadır. Orta İran boylamlarında ise kısalma Zagros $(7 \pm 2 \mathrm{~mm} / \mathrm{yll})$ ve Alborz kıvrım kușakları üzerinde $(8 \pm 2 \mathrm{~mm} / \mathrm{yll})$ dağılımıștır (Vernant vd., 2004; Hessami ve Jamali, 2006). Doğu ve Orta İran arasındaki iletilen kabuksal hızlardaki fark Lut bloğunun doğusu ve batısını sınırlandıran faylar boyunca karșılanmaktadır.

KB-GD doğrultulu ve sağ-yanal doğrultu atımlı 1997 Qa'enat depremi yüzey kırı̆ı̆, kuzeyde D-B solyanal doğrultu atımlı fay sistemi olan Dasht-e-Bayaz fay sistemi ile kesișmektedir (Șekil 1b). Bu nedenle Qa'enat depremi, yüzey kırı̆ı̆ı içeren büyük bir deprem olmasının yanı sıra kıtasal blokları sınırlayan doğrultu atımlı fayların kesișme bölgelerinin nasıl davrandığı ve aynı fay uzunluğu boyunca farklı zamanlarda olușan deprem kırımalarının birbirleri ile olan ilișkilerinin irdelenmeleri açısından önem arz etmektedir. Bu çalıșmada yapılacak sonlu-fay ters çözümüyle elde edilecek kayma modelinin bu irdelemeye olanak sağlayacak bir gayret olacağı düșünülmektedir.

\section{KULLANILAN VERi}

10 Mayıs 1997 Qa'enat depremi sonlu-fay ters çözümünde, episantral uzaklıkları $36^{\circ}$ ile $89^{\circ}$ arasında değișen 21 istasyondaki geniș-bant $P$ dalga șekli ile 16 istasyondaki geniș-bant $S H$ dalga șekli kullanılmıștır. $P$ ve $S H$ dalga șekilleri alet tepkileri giderildikten sonra verilerin karmașıklığı ve yüksek frekans içeriği dolayısıyla, $0.01-0.5 \mathrm{~Hz}$ frekans aralı̆ında Butterworth bantgeçișli filtre kullanılarak filtrelenmiș ve $0.20 \mathrm{sn}$ örnekleme aralığı ile tekrar örneklenmiștir. Ters çözümde hız kayıtları kullanılmıș olup $P$ dalga șekilleri için 50 sn'lik kayıt uzunluğu, $S H$ dalga șekilleri için 60 sn'lik kayıt uzunluğu seçilmiștir.

\section{SONLU-FAY MODEL PARAMETRIZASYONU}

1997 Qa'enat depreminin olușturduğu yüzey kırlğı incelendiğinde yüzey kırığının tek bir doğrultuya 


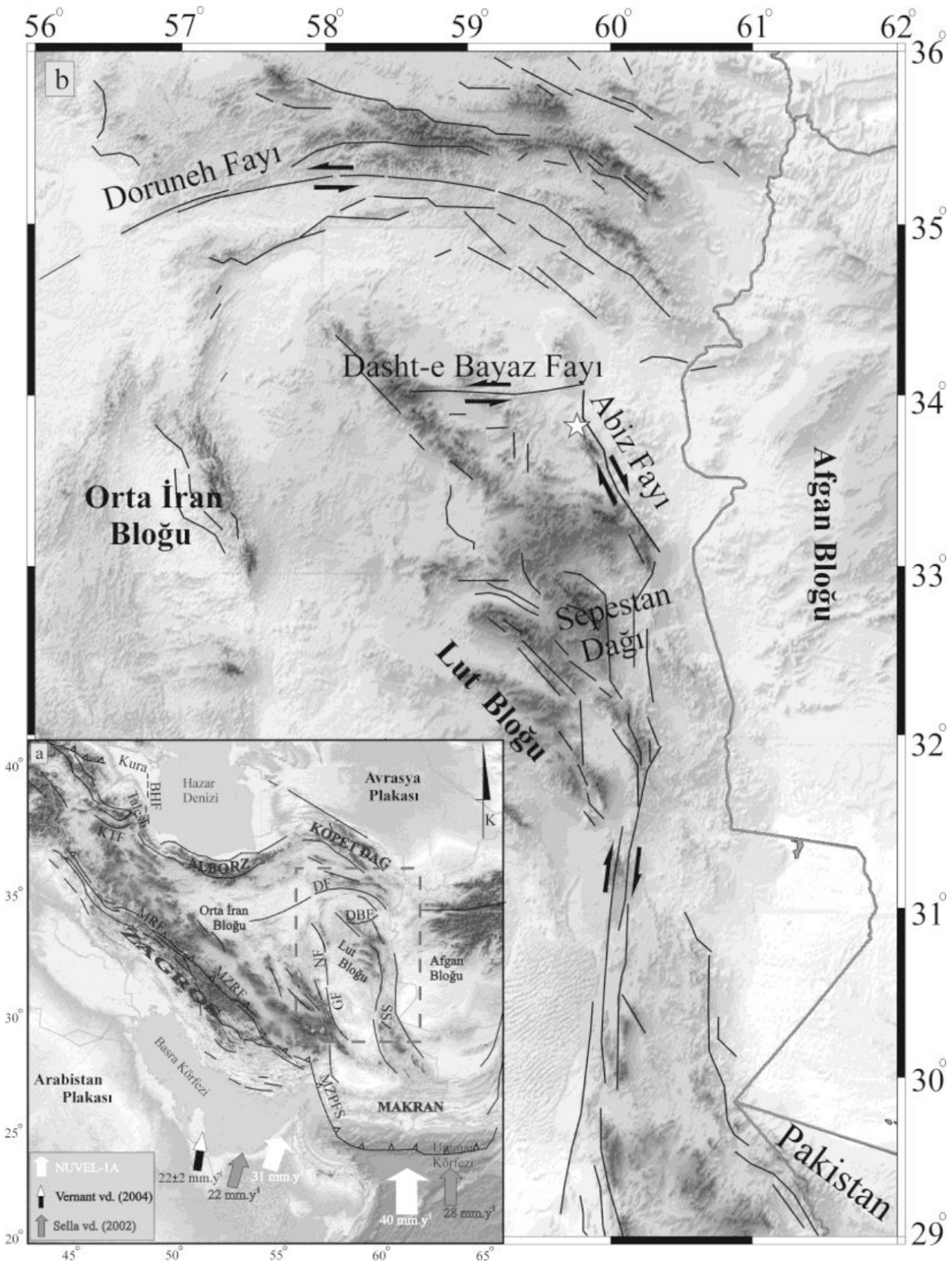

Şekil 1. a) İran'ın basitleştirilmiş tektonik haritası. Büyük oklar NUVEL-1A, Vernant vd. (2004) ve Sella vd. (2002) tarafından verilen Arabistan plakasının Avrasya'ya göre göreceli hareketini temsil etmektedir. Siyah çizgiler aktif fayları temsil etmektedir ve Vernant vd. (2004)'ten alınmıştır. BHF: Batı Hazar Fayı, DBF: Dasht-e Bayaz Fayı, DF: Doruneh Fayı, GF: Gowk Fayı, KTF: Kuzey Tebriz Fayı, MZPFS: Minab-ZendanPalami Fay Sistemi, MRF: Main Recent Fayı, MZRF: Main Zagros Reverse Fayı, NF: Nayband Fayı, SSZ: Sistan Sutur Zonu b) Doğu İran'daki belli bașlı faylar ve Lut bloğunu çevreleyen fay sistemleri. Beyaz yıldız depremin episantrını temsil etmektedir. Faylar Walker ve Khatib (2006)'dan alınmıștır

Figure 1. a) Simplified tectonic map of Iran. Large arrows represent movement of the Arabian plate relative to the Eurasian Plate given by the NUVEL-1A, Vernant et al. (2004) and Sella et al. (2002). Black lines represent active faults that were taken from Vernant et al. (2004). BHF: West Hazar Fault, DBF: Dasht-e Bayaz Fault, DF: Doruneh Fault, GF: Gowk Fault, KTF: North Tebriz Fault, MZPFS: Minab-Zendan-Palami Fault System, MRF: Main Recent Fault, MZRF: Main Zagros Reverse Fault, NF: Nayband Fault, SSZ: Sistan Suture Zone b) The major faults in the Eastern Iran and the fault systems surrounding the Lut block. White star represents epicenter of the earthquake. The faults were taken from the Walker and Khatib (2006). 


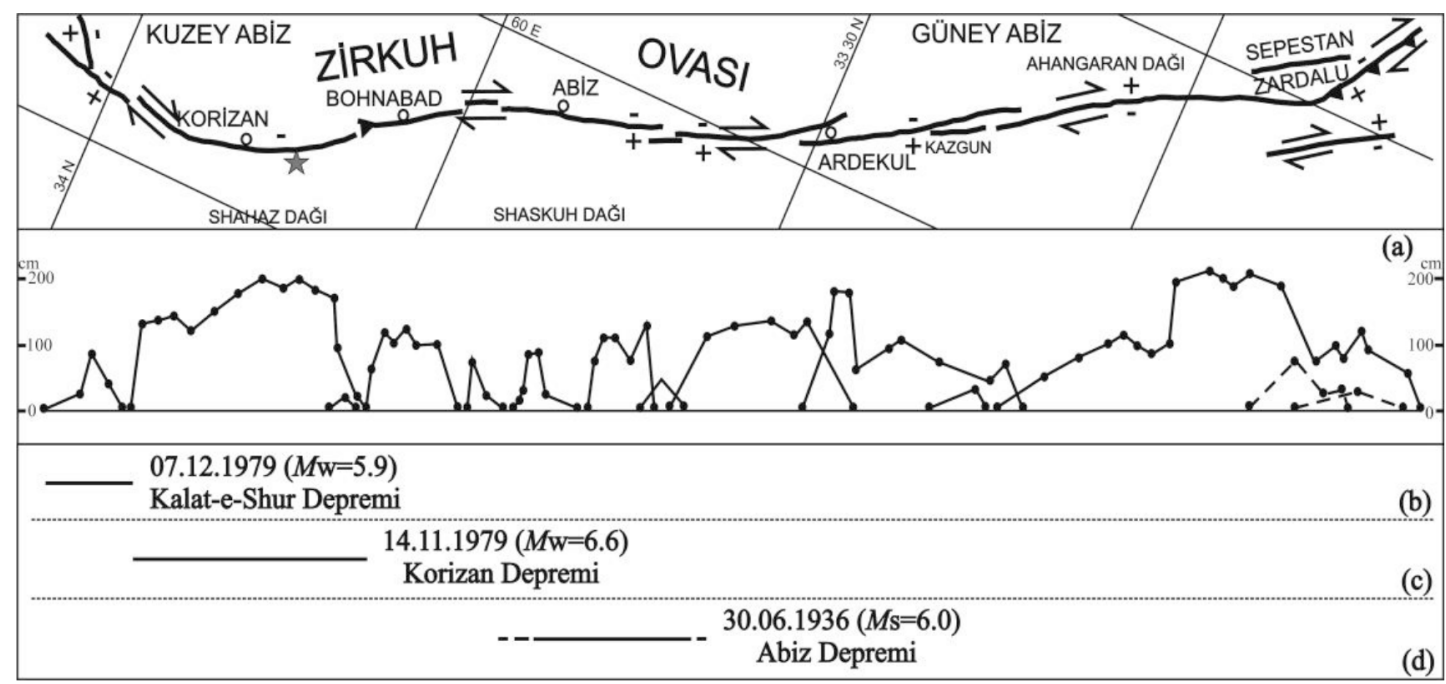

Șekil 2. 10 Mayıs 1997 Qa'enat depreminin yüzey kırığı. (a) Yüzey kırığı boyunca ölçülen yer değiștirme miktarları ve (b), (c) ve (d) yüzey kırı̆ı boyunca sırasıyla 1979 Kalat-e-Shur, 1979 Korizan ve 1936 Abiz depremlerinin tahmini kırılma uzanımlarını göstermektedir. Gri yıldız depremin episantrını temsil etmektedir. (Berberian vd. (1999)'dan değiștirilerek alınmıștır)

Figure 2. The surface rupture of the 10 May 1997 Qa'enat earthquake. (a) Amount of displacements measured along the surface rupture and (b), (c) and (d) show the approximate rupture extends of the 1979 Kalat-eShur, the 1979 Korizan and the 1936 Abiz earthquakes, respectively, along the surface rupture. Grey star represents epicenter of the earthquake (after Berberian et al. (1999)).

Çizelge 1. 10 Mayıs 1997 Qa'enat depreminin çeșitli araștırmacılar ve kurulușlar tarafından verilen kaynak parametreleri.

Table 1. The source parameters of the 10 May 1997 Qa'enat earthquake given by various researchers and organizations.

\begin{tabular}{|c|c|c|c|c|c|c|c|}
\hline & $\begin{array}{c}\text { Enlem } \\
\left({ }^{\circ}\right)\end{array}$ & $\begin{array}{c}\text { Boylam } \\
\left({ }^{\circ}\right)\end{array}$ & $\begin{array}{c}\text { Derinlik } \\
\text { (km) }\end{array}$ & $\begin{array}{c}\text { Mo } \\
\left(\times 10^{19} \mathrm{Nm}\right)\end{array}$ & $\begin{array}{l}\text { Doğrultu } \\
\left(^{\circ}\right)\end{array}$ & $\underset{\left({ }^{\circ}\right)}{\text { Eğim }}$ & $\begin{array}{c}\text { Rake } \\
\left({ }^{\circ}\right)\end{array}$ \\
\hline HRV(Harvard) & - & - & 27 & 7.70 & 338 & 89 & 177 \\
\hline USGS & 33.83 & 59.81 & 10 & 5.40 & 340 & 88 & -179 \\
\hline Berberian vd. (1999) ${ }^{1}$ & 33.83 & 59.81 & 15 & 6.63 & 333 & 86 & 173 \\
\hline Sudhaus ve Jonsson (2011) & 33.52 & 60.02 & 6 & 7.64 & 154 & 88 & 192 \\
\hline
\end{tabular}

${ }^{1}$ Telesismik $\mathrm{P}$ ve SH dalga șekillerinin ters çözümünden; ${ }^{2}$ InSAR verilerinin ters çözümünden.

${ }^{1}$ From the inversion of teleseismic $\mathrm{P}$ and $\mathrm{SH}$ waveforms; ${ }^{2}$ From the inversion of InSAR data.

sahip olmadığı görülmektedir (Șekil 2) (Berberian vd., 1999). Kırı̆ı̆ın kuzey kısmı (kuzeyde Dasht-e-Bayaz fayından güneyde Ardekul'a kadar), batıda Shahaz ve Shaskuh dağları ile doğuda Zirkuh ovası arasında yer alır. Bu kısımda kırığın doğrultusu, kuzeyde Dasht-e-Bayaz fayı ile kesiștiği bölgede $10^{\circ}$ den, Korizan kasabasına yakın K-G doğrultuya ve Bohnabad yakınlarında $155^{\circ}$ 'ye değișerek önemli ölçüde değișim göstermiștir. Ayrıca doğrultunun tekrar $155^{\circ}$ olduğu Bohnabad ile Ardekul arasında bir bükülme (S șeklinde) meydana gelmiștir. Ardekul'un güneyindeki yüzey kırıklarının doğrultusu ise $33.16^{\circ} \mathrm{K}-60.23^{\circ} \mathrm{D}$ koordinatından çarpıcı șekilde $125^{\circ}$ ye değișir.

Çalıșmada, model parametrizasyonunun karmașıkIığını azaltmak amacıyla haritalanan yüzey kırığında yaklașık aynı doğrultuya sahip fay segmentleri tek segment kabul edilerek 5 segmentli bir sonlu-fay modeli olușturulmuștur (Șekil 3, Çizelge 2). Buna göre yüzey kırığının Korizan kasabasının kuzeyinde 


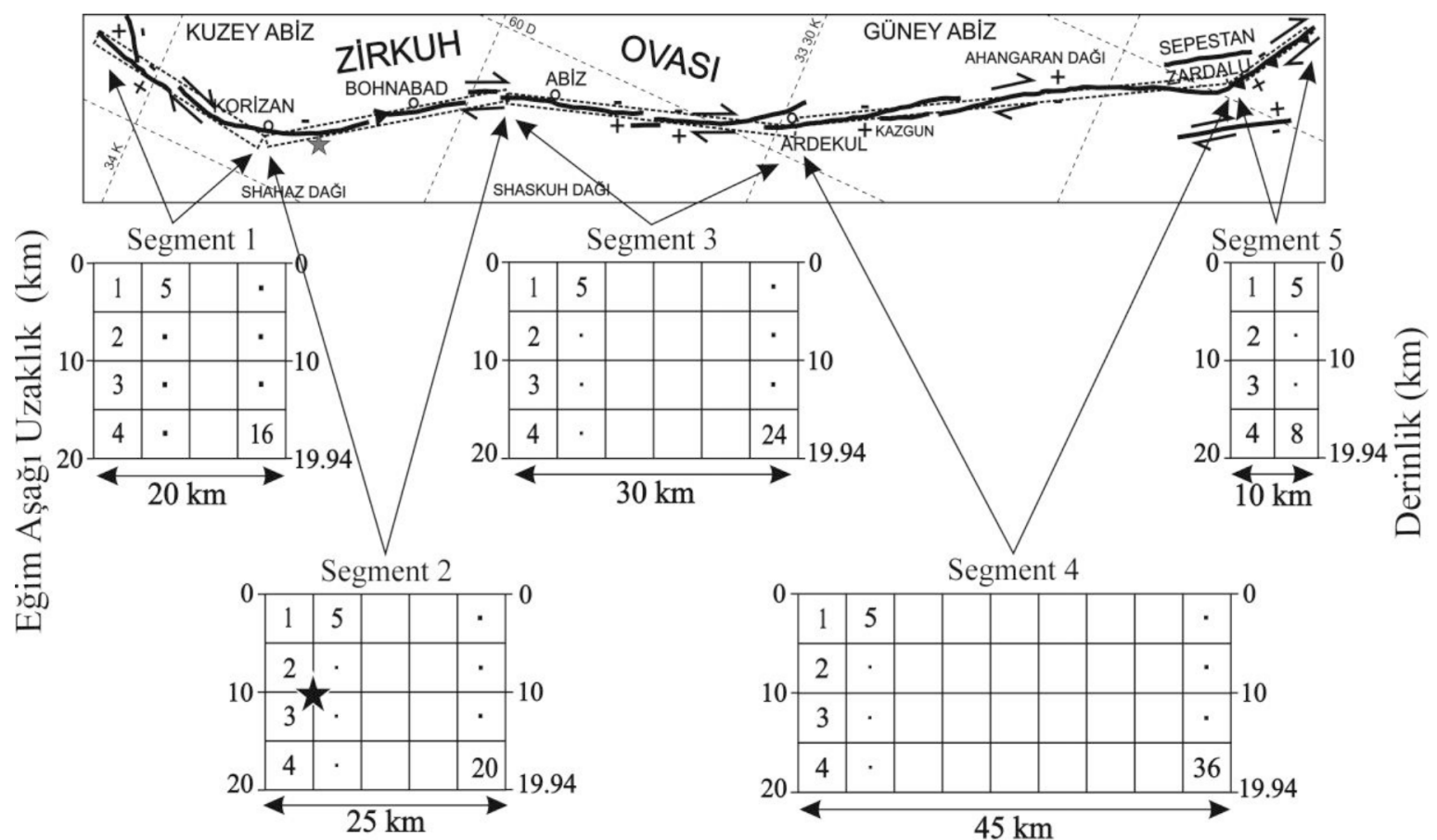

Doğrultu Boyunca Uzaklık (km)

Şekil 3. 10 Mayıs 1997 Qa'enat depreminin yüzey kırığı ve ters çözüm için kullanılan beș segmentli sonlu-fay modeli. Siyah kesikli çizgili dikdörtgenler fay modelinin yüzey izdüșümünü ve gri yıldız depremin odağını temsil etmektedir. Yüzey kırı̆ı̆ uzanımı Berberian vd. (1999)'dan alınmıștır

Figure 3. The surface rupture of the 10 May 1997 Qa'enat earthquake and the five-segment finite-fault model used for the inversion. Black dashed outlined rectangles represent surface projection of the model fault and the grey star shows the earthquake epicenter. Extent of the surface rupture has been taken from Berberian et al. (1999)

Çizelge 2. 10 Mayıs 1997 Qa'enat depremi sonlu-fay ters çözümünde kullanılan çok segmentli fay modeli parametreleri.

Table 2. The multi-segment fault model parameters used in the 10 May 1997 Qa'enat earthquake finite-fault inversion.

\begin{tabular}{lccccc}
\hline & Uzunluk (km) & Genișlik (km) & Doğrultu ( $\left(^{\circ}\right.$ & Eğim ( $\left(^{\circ}\right)$ & $\begin{array}{c}\text { Fay Parçası } \\
\text { Sayısı }\end{array}$ \\
\hline Segment 1 & 20 & 20 & 190 & 87 & 16 \\
Segment 2 & 25 & 20 & 140 & 87 & 20 \\
Segment 3 & 30 & 20 & 164 & 87 & 24 \\
Segment 4 & 45 & 20 & 330 & 87 & 36 \\
Segment 5 & 10 & 20 & 118 & 87 & 8 \\
\hline
\end{tabular}

kalan kısmı bir segmentle (Segment1), Korizan ile Abiz kasabasının hemen kuzeyi arasında kalan kısım bir segmentle (Segment 2), Abiz'in hemen kuzeyi ile Ardekul kasabası arasında kalan kısım bir segmentle (Segment 3) ve Ardekul kasabasının güneyindeki yüzey kırıkları açık șekilde farklı doğrultuya sahip olduklarından dolayı iki farklı segmentle (sırasıyla Segment 4 ve Segment 5) temsil edilmiștir. Bu fay segmentlerinin eğimleri $87^{\circ}$ olarak tanımlanmıș ve her bir segmentin eğim așağı genișliği $20 \mathrm{~km}$ olarak seçil- 
miștir. Modellemede fayın üst kenarı yer yüzeyi ile çakıștııılı̆̆ından $87^{\circ}$ eğime sahip fay modeli 19.94 $\mathrm{km}$ derinliğe kadar uzanmaktadır (Șekil 3).

Kullanılan ters çözüm metodu gereği çok segmentli model fay düzlemi, $5 \mathrm{~km} \times 5 \mathrm{~km}$ boyutlarında toplam 104 adet fay parçasına bölünmüș (Șekil 3) ve 36 nokta kaynak her bir fay parçası üzerine düzgün olarak dağıtılmıștır. Berberian vd. (1999) da olduğu gibi USGS'in belirlediği dıș merkez koordinatları $\left(33.83^{\circ} \mathrm{K}-59.81^{\circ} \mathrm{D}\right)$ kııılmanın bașlangıç noktası olarak alınmıștır. Bu dıș merkez noktasının çalıșmada kullanılan fay modeli üzerine izdüșümü yaklașık 10 km derinliğe karșılık gelmektedir.

Modellemede fay parçası sentetik sismogramlarının hesaplanması için kıııma hızının bașlangıçta verilmesi gerekmektedir. Deprem sırasındaki kırıma hızının ne olduğuna dair herhangi bir bilginin olmayıșından dolayı bașlangıçta verilmesi gereken kıııma hızı, Necioğlu (1999) tarafından verilen bölgesel kabuksal hız yapısında (Çizelge 3) üst kabuktaki ortalama makaslama dalga hızının \%85'ine karșlık gelen değer olan $3.3 \mathrm{~km} / \mathrm{sn}$ olarak alınmıștır.

Ters çözümde 6 zaman penceresi kullanılmıștır ve her bir zaman penceresi içinde kaynak yükselim-zaman fonksiyonu 0.5 sn yükselim ve 0.5 sn düșüme sahip eșkenar üçgen ile temsil edilmiștir. Her bir zaman penceresi bir öncekinden 1 sn geciktirilmiștir. Böylece fay düzlemi üzerindeki her bir noktada toplam 6 sn'lik bir yükselim zamanına olanak sağlanmıștır. Farklı sabit rake açıları ve rake açısının $90^{\circ}-180^{\circ}$ arasında serbest bırakıldığı birçok ters çözüm denemesi yapılarak sonuçlar karșılaștııımıștır.

\section{TERS ÇÖZÜM SONUÇLARI}

1997 Qa'enat depremi için çok segmentli bir fay modeli parametrizasyonuna değinilmiș olsa da tek segmentli fay modeli ile de gözlenmiș dalga șekilleri modellenmeye çalıșıııș ve birkaç deneme sonucunda tek segmentli model ile bu depremin modellenemeyeceği anlașılmıștır. Çok segmentli fay modeli için farklı rake açılarııın ve kıııma hızlarının kullanıldığı birçok ters çözüm denemesinin yanı sıra farklı eğim yönleri için de denemeler yapılmıștır (Çizelge 4). Illk iki denemede (Model QM1 ve QM2) tüm segmentlerin eğim yönleri aynı kabul edilmiș (QM1'de B-KB, QM2'de D-KD), üçüncü denemede ise (Model QM3) dördüncü segmentin eğim yönü Berberian vd. (1999) ve Sudhaus ve Jonsson (2011) tarafından belirtildiği gibi diğer segmentlerden farklı olarak doğuya eğimli kabul edilmiștir.

QM3 modeli ile yapılan denemede elde edilen hata miktarı ilk iki denemenin hata miktarından daha düșük çıkmıș (Çizelge 4) ve daha sonra rake açısı ve kırıma hızlarının değiștirildiği birçok ters çözüm denemesi yapılmıștır. Bașlangıç olarak kırılma hızı $3.3 \mathrm{~km} / \mathrm{s}$ alınmıș ve rake açıları ise Berberian vd.(1999)'da belirtilen faylanma türlerine göre her bir segment için ayrı ayrı tanımlanmıștır. Buna göre ilk dört segment için sağ-yanal doğrultu atımlı faylanmayı temsil eden, beșinci segment için ise sağ-yanal doğrultu atım ve ters atım bileșen içeren rake açıları seçilmiștir. Çizelge 4'de görüldüğü gibi yapılan tüm ters çözüm denemeleri sonucunda en küçük hata miktarı Model QM7 ile elde edilmiștir.

Model QM7 ters çözüm denemesi sonucunda elde edilen kayma dağıım modeli Șekil 4'de verilmiștir. Bu model için hesaplanan sentetik dalga șekilleri ile

Çizelge 3. 10 Mayıs 1997 Qa'enat depreminin sonlu-fay analizinde kullanılan kabuksal hız modeli (Necioğlu, 1999). Table 3. The crustal velocity model used in the 10 May 1997 Qa'enat earthquake finite-fault analysis (Necioğlu, 1999).

\begin{tabular}{cccc}
\hline Kalınlık $(\mathbf{k m})$ & $\mathbf{V}_{\mathbf{p}}(\mathbf{k m} / \mathbf{s})$ & $\mathbf{V}_{\mathbf{s}}(\mathbf{k m} / \mathbf{s})$ & $\rho\left(\mathbf{g r} / \mathbf{c m}^{3}\right)$ \\
\hline 3.0 & 5.20 & 3.00 & 2.55 \\
9.0 & 6.10 & 3.52 & 2.69 \\
17.0 & 6.50 & 3.75 & 2.85 \\
23.0 & 6.80 & 3.90 & 3.00 \\
- & 8.15 & 4.70 & 3.40 \\
\hline
\end{tabular}




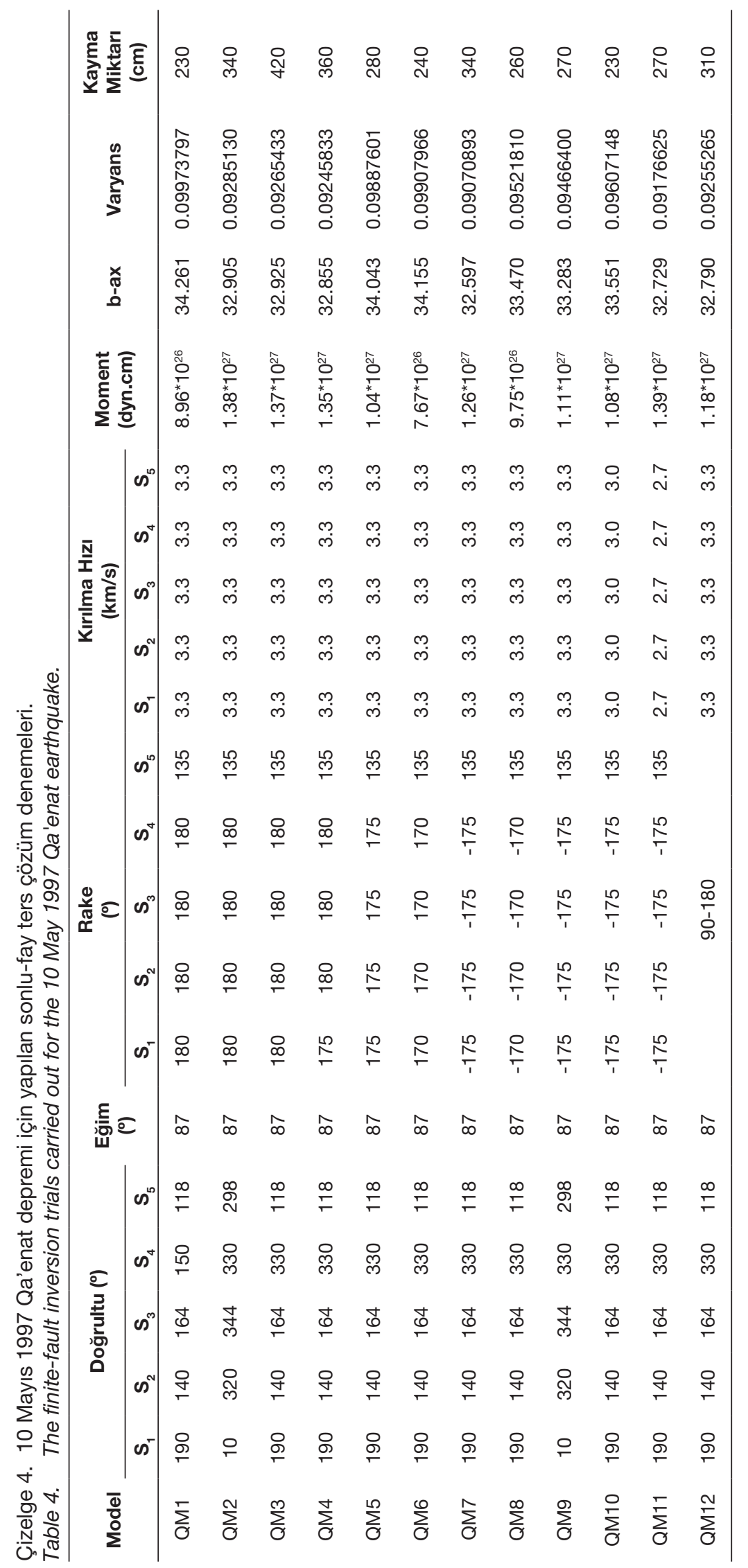




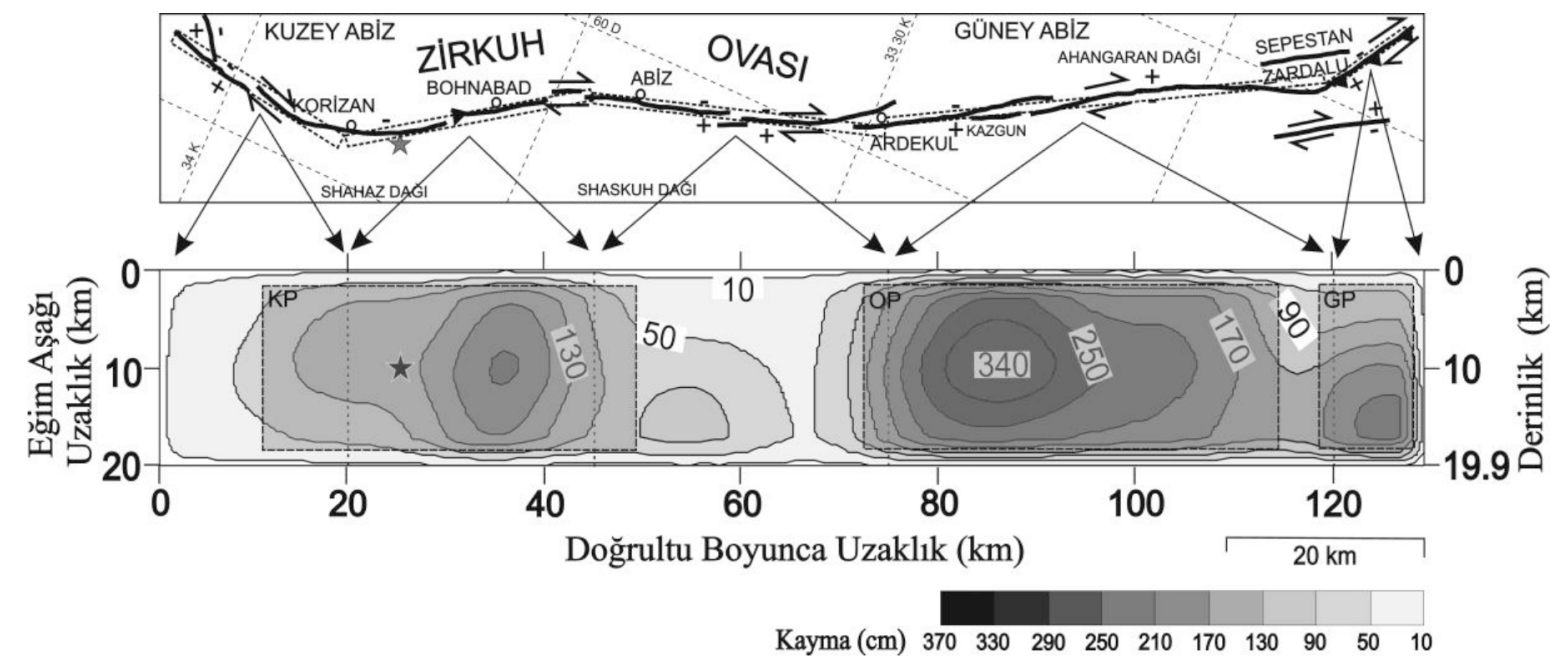

Şekil 4. 10 Mayıs 1997 Qa'enat depremi yüzey kırıkları haritası (üstte) ve sabit rake açııı kullanılarak yapılan ters çözüm denemeleri sonucu tercih edilen kayma dağılım modeli (altta). Kayma dağııımı Tablo 4'de Model QM7'ye karșılık gelmektedir. 10 cm'den büyük kaymalar $40 \mathrm{~cm}$ aralıklarla konturlanmıștır. Yüzey kırıkları Berberian vd. (1999)'dan alınmıștır. Yıldız depremin odağını temsil etmektedir. Siyah kesikli çizgili dikdörtgenler fay modelinin yüzey izdüșümünü ve kuzey, orta ve güney pürüzleri (sırasıyla KP, OP ve GP) çevrelenmiștir.

Figure 4. The map of surface ruptures of the 10 May 1997 Qa'enat earthquake (top) and the slip distribution model preferred for the fixed-rake inversion trials (bottom). The slip distribution corresponds to Model QM7 in Table 4. Slips larger than $10 \mathrm{~cm}$ are contoured with $40 \mathrm{~cm}$ intervals. The surface rupture has been taken from Berberian et al. (1999). Star represents hypocenter of the earthquake. Black dashed outlined rectangles represent surface projection of the model fault and northern, middle and southern asperities (KP, MP and $S P$, respectively) are enclosed.

gözlenmiș dalga șekilleri ise Șekil 5'de karșılaștırılmıștır. Elde edilen kayma dağılım modeli incelendiğinde (Șekil 4) depremin üç fay pürüzünün kırıması ile oluștuğu ve en büyük yer değiștirmenin $3.5 \mathrm{~m}$ civarında olduğu görülmektedir.

\section{TARTIȘMA}

Üç fay pürüzünden kırımanın başladığı Kuzey Pürüzü $(\mathrm{KP})$, yüzey kırı̆ı̆ın Korizan kasabasının kuzeyi ile Abiz kasabası arasındaki kesiminde yerleşmiş olup maksimum kayması $220 \mathrm{~cm}$ 'dir. KP yaklaşık 30×15 $\mathrm{km}^{2}{ }^{2} l i k$ bir fay alanında $100 \mathrm{~cm}$ ve üzeri kayma değerlerine sahiptir. Maksimum kaymanın 340 cm'yi aștığı Orta Pürüz (OP) ise Ardekul kasabası ile güneydoğuda yüzey kırıklarının GD’ya doğru keskin bir doğrultu değiștirdiği kısım arasında yerleșmiștir. 1997 Qa'enat depreminin en güneyindeki ve en küçük kırılma alanını örten pürüzünü teșkil eden Güney Pürüzü (GP) ise yaklașık $15 \times 15 \mathrm{~km}^{2}$ lik bir kırılma alanına sahiptir.

Sabit rake açısı kullanılarak yapılan ters çözüm denemelerinin ardından rake açısının serbest bırakıldığı bir ters çözüm denemesi yapılmıștır (Çizelge 4, Model QM12). Yüzey kırığının en güneyinde gözlenen önemli ters faylanmalı kayma (Șekil 2) gözetilerek rake açısı $90^{\circ}-180^{\circ}$ arasında serbest bırakılmıștır. Bu ters çözüm denemesi sonucu elde edilen kayma dağılım modeli ve bu model için hesaplanan sentetik sismogramlarla gözlenmiș sismogramların karșılaștırılması sırasıyla Șekil 6 ve 8'de verilmiștir. Șekil 4 ve 6'daki kayma dağılım modellerinin karșılaștırımasından görüleceği üzere rake açısının sabit alınması veya $90^{\circ}-180^{\circ}$ arasında serbest bırakılması ile elde edilen kayma dağılımları genel anlamda birbirine benzerlik göstermektedir. Vurgulanabilecek farklar her üç pürüz için de en büyük kayma değerlerinin değișken rake açılı model için daha düșük olması ve GP'nin daha sığda yerleșmesi șeklinde sıralanabilir. Șekil 6 ayrıca kaymanın doğrultu atımlı ve ters atımlı kayma bileșenlerini de göstermektedir. Görüleceği üzere 1997 Qa'enat depremi kırımasında doğrultu atımlı kayma bileșeni baskındır. Ancak, faylanmanın en güneyindeki 20 km'lik bölümünde ters faylanmalı kaymanın sağ-yanal kaymaya denk genliklere eriștiği de not edilmelidir ki bu sonuç, depremin haritalanan 
10 Mayıs 1997 Qa'enat Depremi, $M \mathrm{w}=7.2$

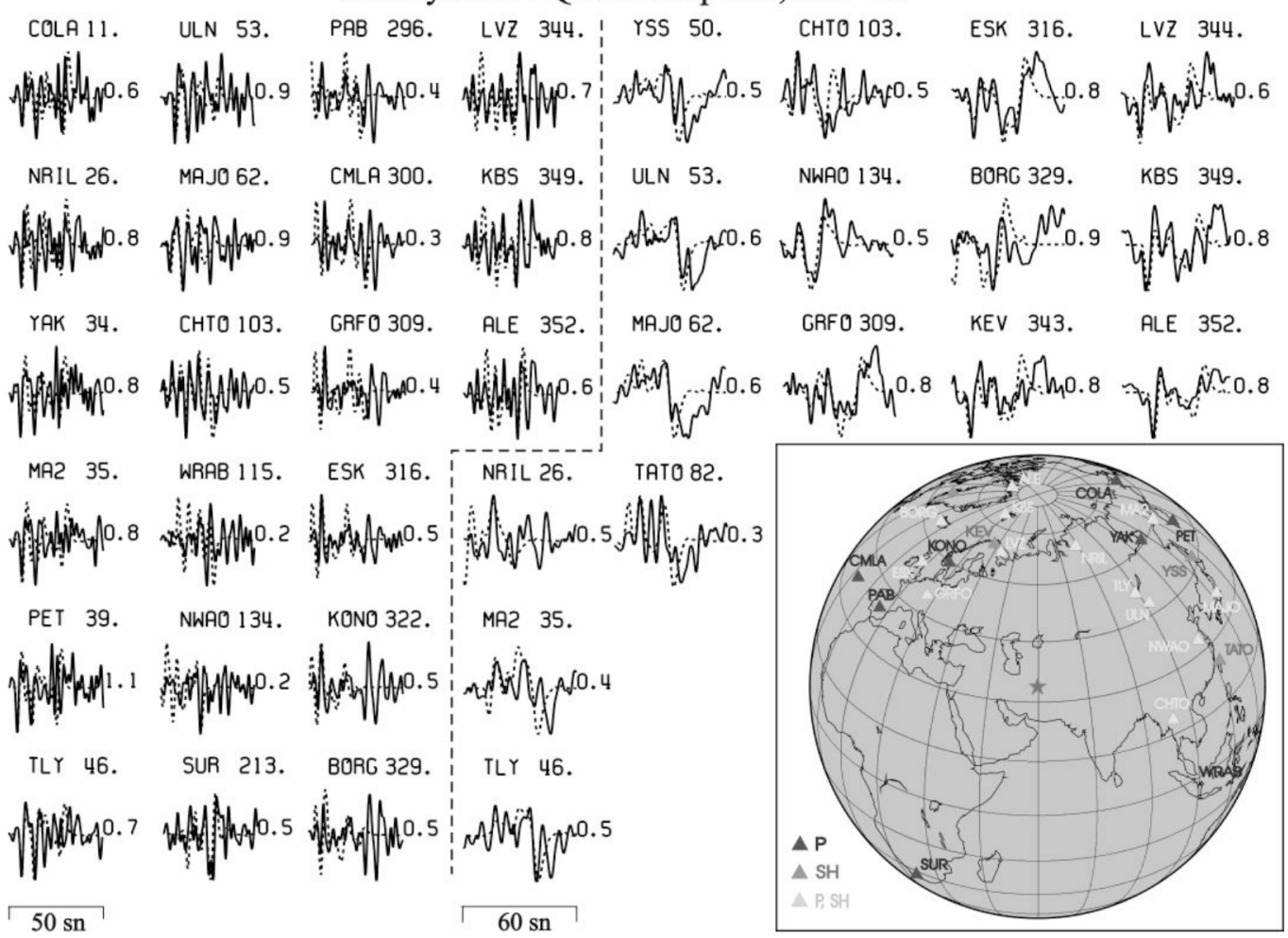

Șekil 5. Gözlenmiș dalga șekilleriyle (sürekli çizgi) sabit-rake açlı ters çözümlerden 10 Mayıs 1997 Qa'enat depremi için tercih edilen kayma dağılım modelinden hesaplanmıș dalga șekillerinin (kesikli çizgi) karșılaștırılması. Sismogram çiftlerinin üstünde istasyon adı ve azimutları ve sağında ise sentetik/gözlenmiș dalga șekli genlik oranları gösterilmiștir. Ters çözümde kullanılan istasyonların azimutal dağılımları sağ alt köșede gösterilmiștir.

Figure 5. The comparison observed waveforms (continuous line) and synthetic waveforms (dashed line) for the preferred slip distribution model resulted from the fixed-rake inversions for the May 10, 1997 Qa'enat earthquake. The station name and azimuths are shown above the pair of seismograms and the synthetic/ observed wave amplitude ratios are shown on the right of the seismogram pairs. The azimuthal distributions of the stations used in the inverse solution are shown in the bottom right corner.

yüzey kırı̆̆ının bu kesiminde yüzeyde gözlemlenen ters atımlı yer değiștirmelerle de uyumludur.

Şekil 6, KP'nin sığ kesimlerinde de genliği 50 cm'yi aşan ters faylanmalı kaymaya işaret etmektedir. Fayın doğrultusunun KB-GD'dan K-G'e değiştiği bu kesimde (Bohnabad yerleşimi civarı) yüzeyde Berberian vd. (1999) $70 \mathrm{~cm}$ 'ye yakın ters atımlı yer değiştirme rapor etmiştir. Bu kayma dağılım modeli için elde edilen sismik moment $1.18 \times 10^{27}$ dyn.cm'dir.

Șekil 4 ve 6'da verilen her iki kayma dağılım modeli de 1997 Qa'enat depremi için genel olarak güneye doğru tek taraflı bir kırılmaya ișaret etmektedir. KP'nin yenilmesiyle bașlayan kırılma, kayma genliğinin 50 $\mathrm{cm}$ civarına düștüğü Abiz ve Ardekul yerleșimleri arasındaki göreceli olarak moment serbestlenmesindeki düșüșün ardından en büyük pürüz OP'nin ve ardından GP'nin yenilmesiyle devam etmiștir. Bu durum kırılmanın uzay-zaman evriminin gösterildiği Șekil 8'de açıkça gözlenebilmektedir.

Kırılma odakta bașlamıș, yaklașık 6 saniye iki yönlü olarak ilermiș (kuzeybatı ve güneydoğuya doğru) ve daha sonra tek yönlü olarak güneydoğuya doğru yayılmasını sürdürmüștür. KP'nin kırılması yaklașık 8 sn sürmüș, OP'nin kırılması 18 ile 30 sn arasında gerçekleșmiș ve bunu son 6 sn'de GP'nin yenilmesi izlemiștir. Toplam kırıma 36 saniye de gerçekleșmiștir. OP'nin en büyük kayma bölgesindeki kaymanın $5 \mathrm{sn}$ civarında sürdüğü görülmektedir. Bu da bu deprem için yükselim zamanının 4-5 sn civarında olduğunu önermektedir. Gheitanchi ve Raeesi (2004), 1997 


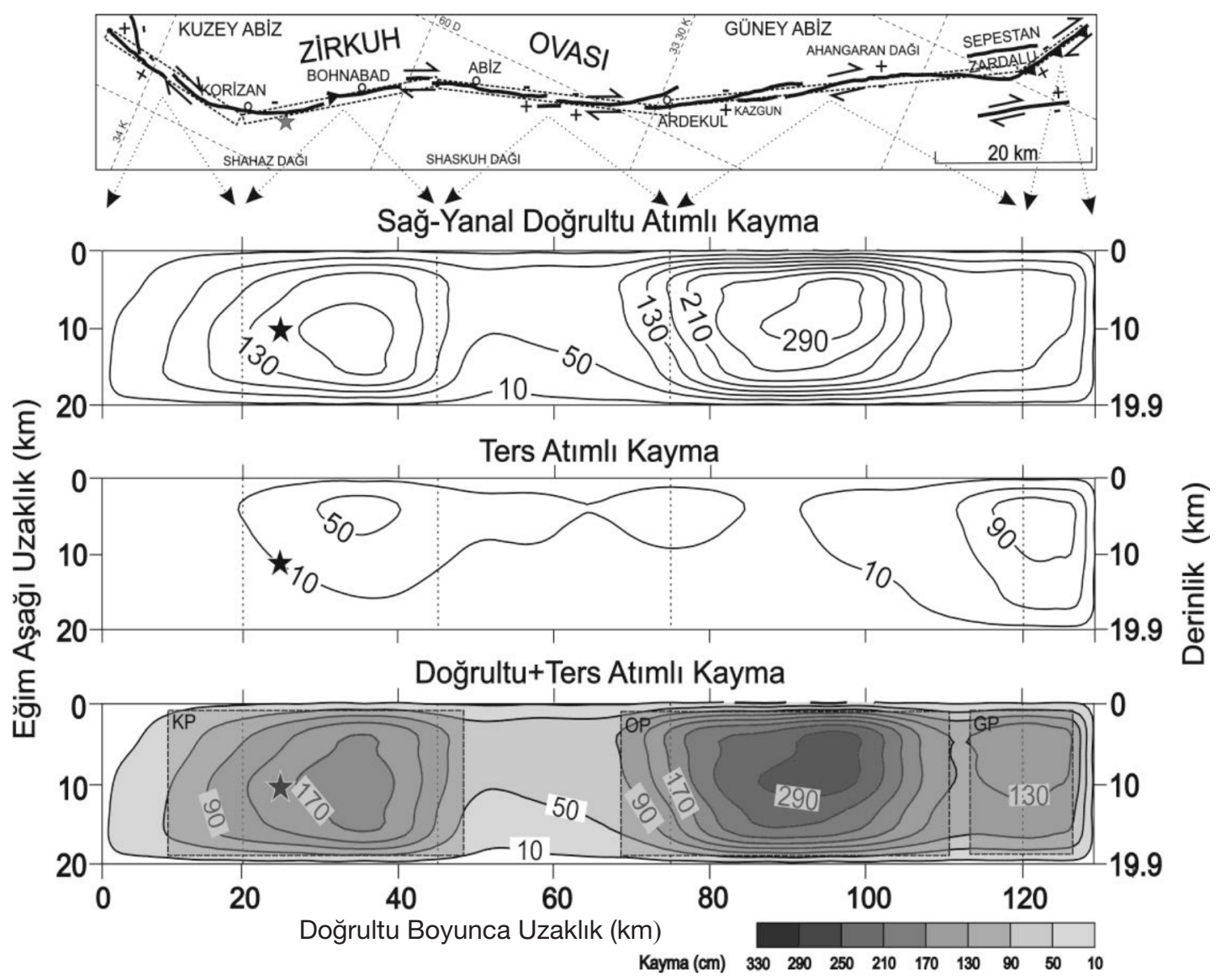

Şekil 6. 10 Mayıs 1997 Qa'enat depremi yüzey kırıkları haritası (üstte) ve değișken rake açısı $\left(90^{\circ}-180^{\circ}\right.$ arasında) kullanılarak yapılan ters çözüm denemeleri sonucu tercih edilen kayma dağılım modeli (altta). Kayma dağılımı Tablo 4'de Model QM12'ye karșılık gelmektedir. $10 \mathrm{~cm}$ 'den büyük kaymalar $40 \mathrm{~cm}$ aralıklarla konturlanmıștır. Yüzey kıııları Berberian vd. (1999)'dan alınmıștır. Yıldız depremin odağını temsil etmektedir. Siyah kesikli çizgili dikdörtgenler fay modelinin yüzey izdüșümünü ve kuzey, orta ve güney pürüzleri (sırasıyla KP, OP ve GP) çevrelenmiștir.

Figure 6. The map of surface ruptures of the 10 May 1997 Qa'enat earthquake (top) and the slip distribution model preferred for the variable-rake (between $90^{\circ}-180^{\circ}$ ) inversion trials (bottom). The slip distribution corresponds to Model QM12 in Table 4. Slips larger than $10 \mathrm{~cm}$ are contoured with $40 \mathrm{~cm}$ intervals. The surface rupture has been taken from Berberian et al. (1999). Star represents hypocenter of the earthquake. Black dashed outlined rectangles represent surface projection of the model fault and northern, middle and southern asperities (KP, MP and SP, respectively) are enclosed.

Qa'enat depreminin artçı deprem aktivitesinin analizini yaptığı çalıșmasında artçı deprem dağılımlarının genel olarak depremin yüzey kırı̆̆ı boyunca KB-GD yönelimli olduğunu vurgulamıștır. Bu da yukarıda Șekil 8 ile açıklanan kırılmanın kuzeybatıda bașlayarak güneydoğuya doğru ilerlediği ifadesini desteklemektedir.

1997 Qa'enat depremi kırılma süreci için literatürde yer alan iki çalıșma bulunmaktadır. Bunlardan biri (Berberian vd., 1999) telesismik $P$ ve $S H$ cisim dalga șekillerinin nokta kaynak ters çözümlemesi, diğeri ise InSAR verilerinden bulunan çok segmentli sonlu- fay kayma dağılım modelidir (Sudhaus ve Jonsson, 2011). Önceki kırılma modelleri bu çalıșmada belirlenen sonlu-fay kayma dağılım modelleri ile Șekil 9'da karșılaștırılmıștır. Genel olarak kaynak modelleri arasında bir benzerlik olduğu söylenebilir (Șekil 9).

Berberian vd (1999)'un 4 alt olaylı (Șekil 9'da S1, S2, S3 ve S4) nokta kaynak modelinde nokta kaynakların, kırılan fay uzunluğu üzerindeki uzay-zaman konumları bu çalıșmada belirlenen pürüz lokasyonları ile uyumludur. Șekil 9'da görüleceği üzere KP, OP ve GP sırasıyla S1, S3 ve S4 alt olayları ile uzay-zaman konumları ve faylanma tipleri açısından benzerlik 
10 May1s 1997 Qa'enat Depremi $M$ w $=7.2$

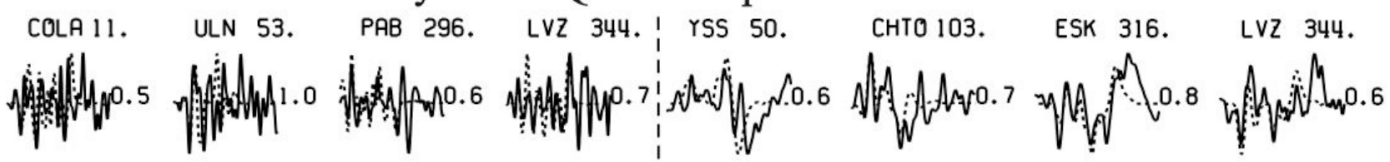

NRIL 26. MAJO 62. CMLA 300. KBS 349.

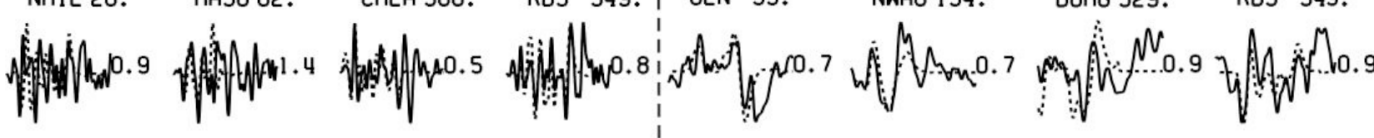

YAK 34. CHTO 103. GRFO 309. ALE 352. MAJO 62. GRFO 309. KEV 343. ALE 352.

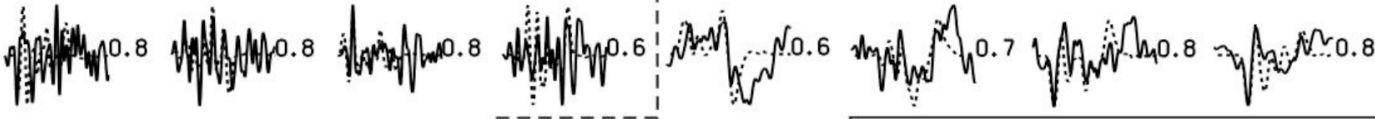

MA2 35. WRAB 115. ESK 316.

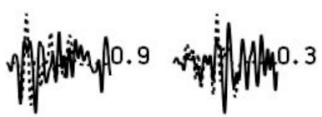

Whatf 0.8

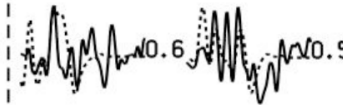

PET 39. NWAO 134 .

KONO 322. МA2 35.

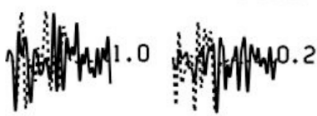

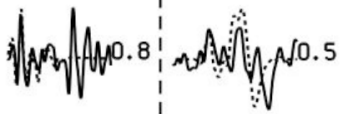

TLY 46.

SUR 213.

BORC 329. I

TLY 46.

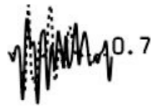

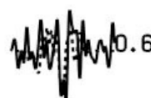

$50 \mathrm{sn}$

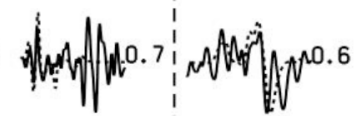

$60 \mathrm{sn}$

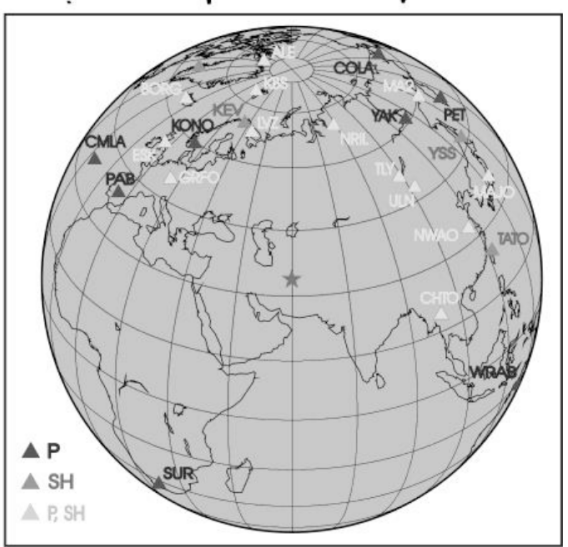

Șekil 7. Gözlenmiș dalga șekilleriyle (sürekli çizgi) değișken-rake açılı ters çözümlerden 10 Mayıs 1997 Qa'enat depremi için tercih edilen kayma dağılım modelinden hesaplanmıș dalga șekillerinin (kesikli çizgi) karșılaștırılması. Sismogram çiftlerinin üstünde istasyon adı ve azimutları ve sağında ise sentetik/gözlenmiș dalga șekli genlik oranları gösterilmiștir. Ters çözümde kullanılan istasyonların azimutal dağılımları sağ alt köșede gösterilmiștir.

Figure 7. The comparison observed waveforms (continuous line) and synthetic waveforms (dashed line) for the preferred slip distribution model resulted from the variable-rake inversions for the May 10, 1997 Qa'enat earthquake. The station name and azimuths are shown above the pair of seismograms and the synthetic/ observed wave amplitude ratios are shown on the right of the seismogram pairs. The azimuthal distributions of the stations used in the inverse solution are shown in the bottom right corner.

göstermektedir. S2 alt olayının olduğu bölgede çalıșmada bulunan gerek sabit ve gerekse değișken rake açlı kayma modelleri göreceli olarak düșük kayma (0.5-1 metre arası) önermektedir. S2'nin S1 ve S3'e göre daha küçük ( $\mathrm{S} 1$ 'den yaklașık 3 kat $\mathrm{S} 3$ 'den yaklașık 5 kat daha küçük) olması da bir benzerlik olarak ifade edilebilir. Ancak S2 sağ-yanal doğrultu atımlı faylanma bileșeni olsa da ters faylanma ağırıklı bir kaynaktır. Bu çalıșmada bulunan değișken rake açılı model bu kaynağın bulunduğu fay alanında ters faylanma bileșenine ișaret etse de ağırlıklı olarak sağyanal faylanma ifade etmektedir (Șekil 9).

Çalıșmada bulunan kayma modelleri ile Sudhaus ve Jonsson (2011)'in InSAR verilerinden bulduğu sonlufay kayma modeli karșılaștırılığında uyum yukarıda söz edilen nokta kaynak modellemesi sonuçlarına göre daha az olmasına rağmen önemli benzerlikler de ifade edilebilir (Șekil 9). InSAR modelindeki Korizan kasabası ve odak güneyinde yer alan 3 metre üzeri kayma ve Ardekul kasabası güneyindeki genel olarak 3 metreden daha az kaymaya sahip pürüzler KP ve OP'nin konumları ile benzerdir. Ancak bu çalıșmadaki modeller OP'nin hem kırılma alanı hem de kayma genliği açısından daha büyük bir pürüz olduğunu önermektedir. GP'nin bulunduğu bölgede InSAR modelinin de ters faylanma ağırlıklı bir faylanma önermesi diğer önemli bir benzerlik olarak ifade edilebilir. En önemli fark Ardekul kasabası kuzeyinde KP ile OP arasındaki kayma boșluğunda yerleșmiș ve kayma genliği yer yer 3 metreyi așan önemli bir 

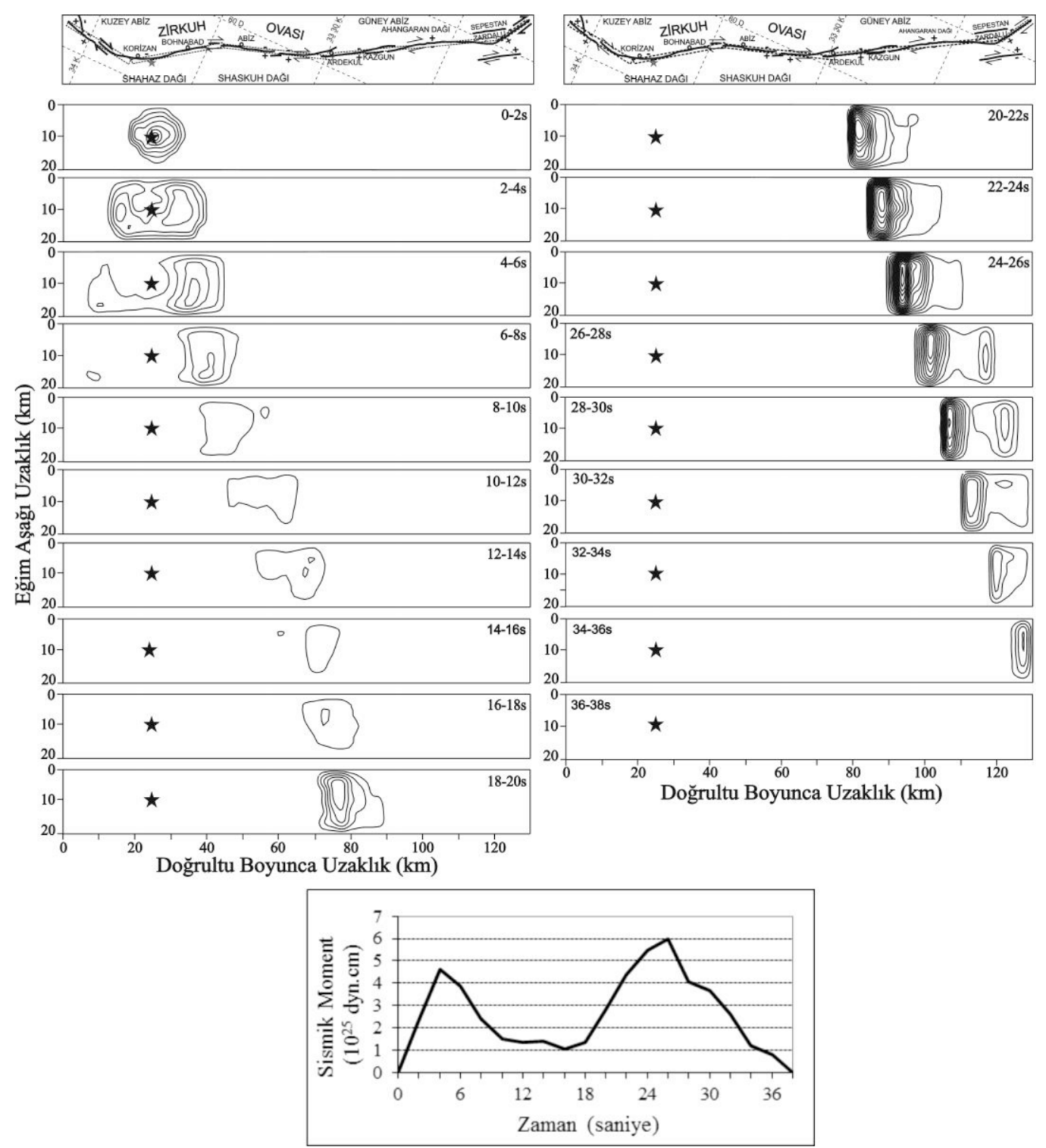

Şekil 8. 10 Mayıs 1997 Qa'enat depremi kırımasının 2 saniye zaman aralıkları ile hesaplanan uzay-zaman evrimi (üstte) ve sismik moment serbestlenmesini tanımlayan kaynak-zaman fonksiyon (altta). $10 \mathrm{~cm}$ 'nin üzerindeki kaymalar $10 \mathrm{~cm}$ aralıklarla konturlanmıștır. Yıldız depremin odağını göstermektedir.

Figure 8. The space-time evolution of the May 10, 1997 Qa'enat earthquake calculated for 2 seconds time intervals (top) and source-time function defining the seismic moment release. The slips over the $10 \mathrm{~cm}$ are contoured with $10 \mathrm{~cm}$ intervals. The star shows hypocenter of the earthquake.

pürüzün InSAR modelinde görülmesidir. Bu pürüzün güney bölümü OP'nin kuzey kenarıyla kayma genliği olarak olmasa da konum olarak örtüșmektedir (Șekil 9).

InSAR ile yapılan çalıșmada bulunan kayma modelleri arasındaki farkların çeșitli nedenleri olduğu tartıșılabilir. En önemli nedenin kullanılan verilerin kayma yükselim zamanına olan duyarlııklarının farklı olması olduğu düșünülmüștür. Çalıșmada deprem dalga șekilleri kullanıldığından bulunan modeller kosismik kayma dağıımlarıdır (kayma yükselim zamanı genel olarak <10sn). Sudhaus ve Jonsson (2011)'in kullandığı InSAR verisi 1997 Qa'enat depremi sonrası 1-2 yıllık bir zaman aralığını kapsamaktadır. Dolayısıyla InSAR kayma dağııımı sadece kosismik değil postsismik kaymayı (kayma yükselim zamanı aylar mertebesinde) ve artçı deprem aktivitesine ait kaymaları 


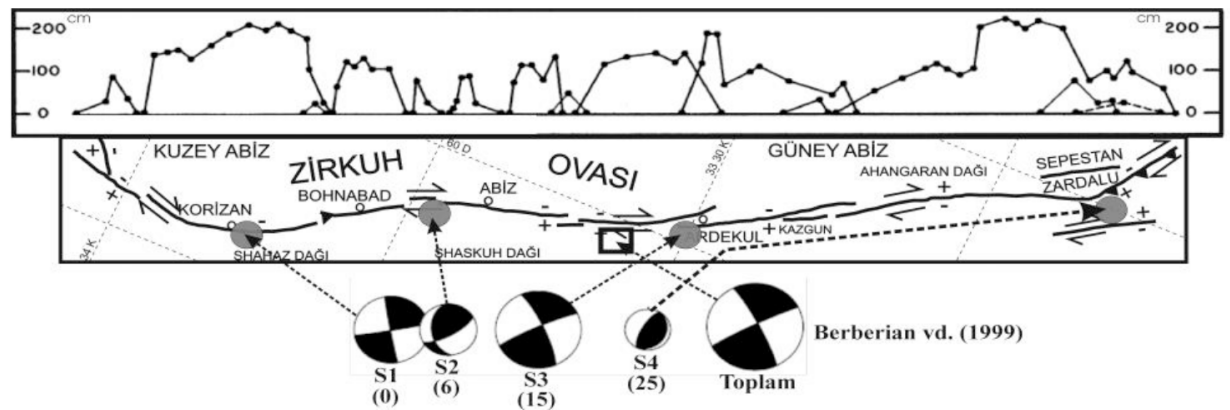

InSAR kayma modeli (Sudhaus ve Jonsson, 2011)

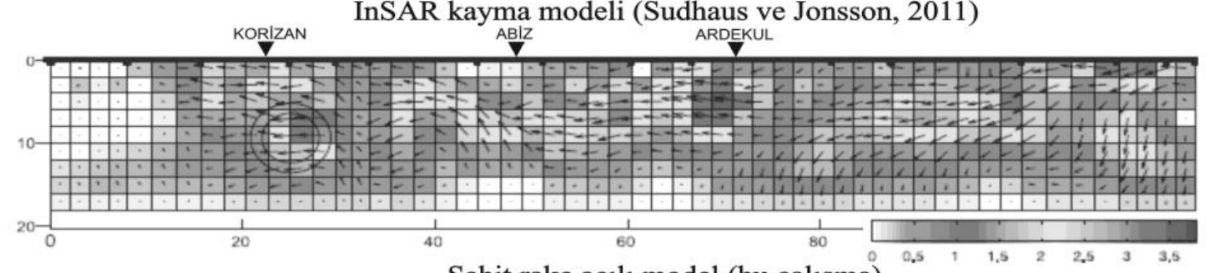

Sabit rake açılı model (bu çalışma)

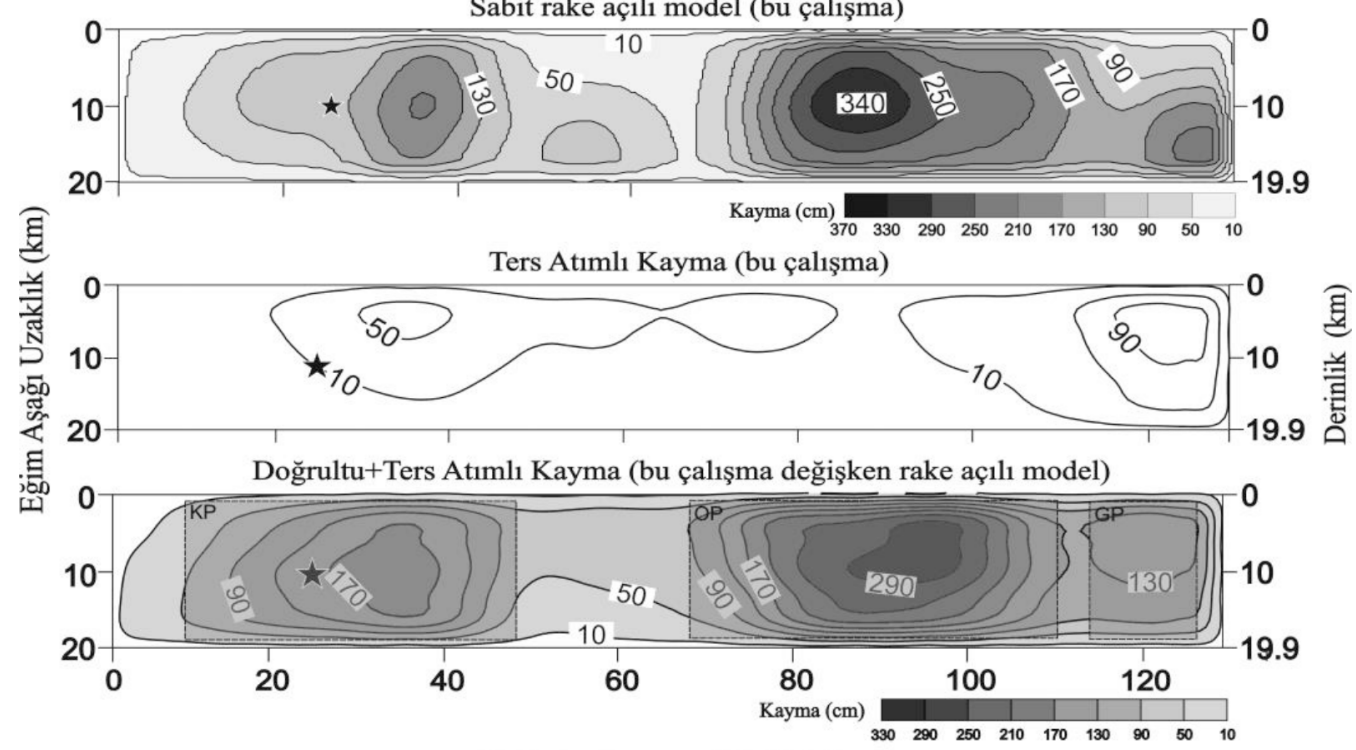

Doğrultu Boyunca Uzaklık (km)

Şekil 9. 10 Mayıs 1997 Qa'enat depremi yüzey kırığı boyunca ölçülen yer değiștirme miktarları (en üst çerçeve), yüzey kırığı uzanımı (üstten ikinci çerçeve), Berberian vd. (1999)'un belirlediği telesismik kırıma sürecindeki nokta kaynakların (S1, S2, S3 ve S4 etiketli siyah daireler) konumları ve kaynak mekanizmaları (siyah-beyaz plaj topları), Sudhaus ve Jonsson (2011)'in InSAR kayma dağlım modeli (üstten üçüncü çerçeve) ve bu çalıșmada bulunan sonlu-fay kayma dağılımları (son üç çerçeve). Nokta kaynaklarının altında parantez içindeki rakamlar, nokta kaynakların kıııma bașlangııından kaç saniye sonra kırıldıklarını temsil emektedir. InSAR kayma modelindeki büyük daire ve çalıșmada bulunan kayma modellerindeki siyah yıldızlar depremin odağını göstermektedir. Kesikli dikdörtgenlerle çevrili gri alanlar pürüzleri temsil etmektedir.

Figure 9. The slip distribution along the May 10, 1997 Qa'enat earthquake's surface rupture (top frame), surface rupture extend (second frame from the top), the location of point sources (solid circles labeled as S1, S2, S3 and S4) and the source mechanisms (black and white beach balls) from the teleseismic rupture process of Berberian et al. (1999), InSAR slip distribution model of Sudhaus and Jonsson (2011) (third frame from the top) and the finite fault slip distribution models from the present study (the last three frames). The numbers in parentheses below the point sources represent their rupture time after the rupture initiation. The large circle in the InSAR slip model and the black stars in the slip models show the hypocenter. The dashed grey areas enclosed with rectangles represent the asperities. 
da içermektedir. Nitekim Sudhaus ve Jonsson (2011), modellerinin ters faylanmalı 16 Haziran 1997 ve doğrultu atım faylanmalı 25 Haziran 1997 artçı depremlerinin kaymalarını da içerdiğini kendileri ifade etmiștir. $\mathrm{Bu}$ açıdan KP ve OP arasında yerleșmiș ve OP'nin kuzey kenarında kaymasının azaldığı bölge ile örtüșen InSAR kayma modelindeki pürüzün kaymasının daha çok postsismik kayma olabileceği tartıșılabilir.

Çalıșmada bulunan kayma modelleri ile InSAR kayma modeli arasında ayrıntıda ifade edilebilecek farkların kullanılan verinin çözünürlüğü ve model parametrizasyonu ile ilișkili olduğu düșünülmektedir. Sudhaus ve Jonsson (2011) 17 segmentli bir fay modeli kullanmıș ve bu fay segmentleri bir kenarı $2.25 \mathrm{~km}$ olan onlarca kare șeklinde fay parçasına bölünmüștür. Bu çalıșmada kullanılan veri bu șekilde bir model parametrizasyonu için yeterli çözünürlülüğe sahip değildir. Bu nedenle InSAR kayma modeli oldukça ayrıntılı iken çalıșmada bulunan kayma modelleri kaynağın göreceli olarak daha genel bir görüntüsünü vermektedir.

\section{SONUÇLAR}

Bu çalıșmada, 10 Mayıs 1997 Qa'enat $(M w=7.2)$ depreminin sonlu-fay kırılma özellikleri telesismik genișbant $P$ ve $S H$ dalga șekillerinin ters çözümünden belirlenmiș ve ters çözüm sonuçları Çizelge 4'de özetlenmiștir. Doğu İran'da Abiz fayı üzerinde meydana gelen ve çok segmentli bir yüzey kırığı üreten 1997 Qa'enat depremi kırılmasının üç fay pürüzünün yenilmesi ile kontrol edildiği ve toplamda kırılmanın 36 sn sürerek yaklașık $1.26 \times 10^{27}$ dyn.cm'lik bir sismik momenti serbestlediği görülmüștür. Kırılmanın bașladığı Kuzey Pürüzü (KP), yüzey kırığının Korizan kasabasının kuzeyi ile Abiz kasabası arasında yerleșmiș olup maksimum kayması 220 cm'dir. KP yaklașık 30x15 km²'lik bir fay alanında $100 \mathrm{~cm}$ ve üzeri kayma değerlerine sahiptir. Maksimum kaymanın 340 cm'yi aștığı Orta Pürüz (OP) ise Ardekul kasabası ile güneydoğuda yüzey kırıklarının güneydoğuya doğru keskin bir doğrultu değiștirdiği kısım arasında yerleșmiștir. 1997 Qa'enat depreminin en güneyindeki ve en küçük kırılma alanını örten pürüzünü teșkil

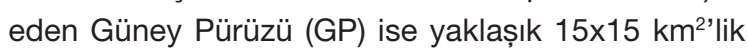
bir kırılma alanına sahiptir. Rake açısının $90^{\circ}-180^{\circ}$ aralığında değișimine izin verildiği ters çözümde kayma genliklerinde küçük farklılıklar ve daha sığ güney pürüzü hariç benzer bir kayma dağılım modeli elde edilmiștir. Değișken rake açılı ters çözüm, depremin baskın olarak sağ yanal kayma nedeniyle olduğunu ve arazide gözlendiği gibi güney pürüzde önemli bir ters kayma bileșenine sahip olduğunu göstermiștir. Değișken rake açılı ters çözüm için sismik moment $1.18 \times 10^{27}$ dyn.cm olarak hesaplanmıștır.

\section{KAYNAKLAR}

Ambraseys, N.N. and Melville, C.P., 1982. A History of Persian Earthquakes. Cambridge University Press, New York.

Berberian, M., 1981. Active faulting and tectonics of Iran, in Zagros, Hindu Kush, Himalaya: Geodynamic Evolution, Geodyn. Ser., vol. 3, edited by H. K. Gupta and F.M. Delany, pp. 33-69, AGU, Washington, D.C., doi: 10.1029/GD003p0033.

Berberian, M., Jackson, J.A., Qorashi, M., Khatib, M.M., Priestley, K., Talebian, M. and Ghafuri-Ashtiani, M., 1999. The 1997 May 10 Zirkuh (Qa'enat) earthquake (Mw 7.2): faulting along the Sistan suture zone of eastern Iran. Geophys. J. Int., 136, 671-694.

Engdahl, E.R., Jackson, J.A., Myers, S.C., Bergman, E.A. and Priestley, K., 2006. Relocation and assessment of seismicity in the Iran region. Geophys. J. Int., 167 (2), 761-778, doi:10.1111/j.1365-246X.2006.03127.x,

Gheitanchi M. R. and Raeesi, M. ,2004. Analysis of the 1997 Zirkuh (Ghaen-Birjand) aftershock sequence in east-central Iran. Acta Seismologica Sinica, 17 (1): 38-46.

Grunthal, G., Bosse, C., Sellami, S., Mayer-Rosa, D. and Giardini, D., 1999. Compilation of the GSHAP regional seismic hazard for Europe, Africa and the Middle East. Annali di Geofisica, Vol. 42, No. 6, 1215-1223.

Hartzell, S. H. and Heaton, T. H., 1983. Inversion of strong ground motion and teleseismic waveform data for the fault rupture history of the 1979 Imperial Valley, California, earthquake. Bull. Seism. Soc. Am. 73, No. 6,1553-1583.

Hessami, K. and Jamali, F., 2006. Explanatory Notes to the Map of Major Active Faults of Iran. JSEE: Spring 2006, Vol. 8, No. 1.

Ikeda, Y., Imaizumi, T., Sato, H., Hessami, K. and Khatib, M.M., 1999. Surface faults associated with the Qayen, northeast Iran, earthqu- 
ake of May 10, 1997. Active Fault Res., 18, 1-13.

Jackson, J. and McKenzie, D., 1984. Active tectonics of the Alpine-Himalayan Belt between western Turkey and Pakistan. Geophys. J. R. Astr. Soc., 77, 185-264.

Necioğlu. A., 1999. Determination of crustal and upper mantle structure between Iran and Turkey from the dispersion of Rayleigh waves. Journal of the Balkan Geophysical Society, Vol. 2, No 4, pp. 139-150.

Sella, G.F., Dixon, T.H. and Mao, A., 2002. REVEL: A model for Recent plate velocities from space geodesy. J. Geophys. Res., Vol. 107, No. B4, 2081, doi:10.1029/2000JB000033.

Sudhaus, H. and Jonsson, S., 2011. Source model for the 1997 Zirkuh earthquake (MW=7.2) in Iran derived from JERS and ERS InSAR observations. Geophys. J. Int., 185, 676-692, doi: 10.1111/j.1365-246X.2011.04973.x.

Talebian, M. and Jackson, J., 2002. Offset on the Main Recent fault of NW Iran and implications for the late Cenozoic tectonics of the Arabia- Eurasia collision zone. Geophys. J. Int., 150, 422-439.
Vernant, P., Nilforoushan, F., Hatzfeld, D., Abbassi, M.R., Vigny, C., Masson, F., Nankali, H., Martinod, J., Ashtiani, A., Bayer, R., Tavakoli, F. and Chery, J., 2004. Present-day crustal deformation and plate kinematics in Middle East constrained by GPS measurements in Iran and northern Oman. Geophys. J. Int., 157, 381-398, doi:10.1111/j.1365246X.2004.02222.

Walker, R.T. and Khatib, M.M., 2006. Active faulting in the Birjand region of NE Iran. Tectonics, Vol. 25, TC4016, doi:10.1029/2005TC001871.

Walker, R.T., Bergman, E.A., Szeliga, W. and Fielding, E.J., 2011. Insights into the 1968-1997 Dasht-e-Bayaz and Zirkuh earthquake sequences, eastern Iran, from calibrated relocations, InSAR and high-resolution satellite imagery. Geophys. J. Int., doi:10.1111/ j.1365-246X.2011.05213.x. 
